\title{
Customary Law-Based Convicts Number Decrement in the Penitentiary
}

\author{
I Ketut Widia \\ \{ketut_widia@yahoo.co.id $\}$ \\ Graduate Program of Legal Science, Universitas Warmadewa, Denpasar, Bali-Indonesia
}

\begin{abstract}
The increasing number of prisoners causes many issues. Every year, captivities are built with considerable number of money and gives burden to government. The cost needs to spend for every custody reached three billion rupiah per month. From legal and economic point of view, this kind of development indicates the failure of realization and implementation of law in society. Empirical evidences have shown that many prisoners continue to commit crimes after released from detention. This phenomenon opens room for a new notion to solve it without jail sentence. Thus, this study offers an alternative to minimize the high number of prisoners in captivity. This study used empirical legal research method. The results of this study indicate that mediation is naturally effective to be applied in resolving legal cases. Regarding the procedural law of customary justice, all forms of cases are settled by deliberation to reach consensus through mediation guided by the customary head.
\end{abstract}

Keywords: Convict decrement; customary law; mediation; penitentiary

\section{Introduction}

Phenomenal conditions regarding the escape of prisoners from the jail, riots, and drug trafficking in prison or controlled from prison have often occurred in almost all prisons in Indonesia. One of the factors of such rampant occurrence of the events is the large number of convicted criminals in the penitentiary. Almost all penitentiaries in Indonesia are inhabited by convicts whose number reaches up to one hundred percent of their exact capacity. As an illustration, if a penitentiary has the capacity to be inhabited by only 500 people, the number of prisoners in each prison reaches 1000 people. It can be imagined how tight the atmosphere in the prison is, plus the limited number of supervisory and security officers. Not only that, every day the state must also spend as much as three billion rupiahs on the budget obtained from collected tax to finance the lives of these prisoners, in addition to the budget used to repair the damaged prisons every time riots among prisoners occur as well as to construct new prisons whose budgets are certainly silencing [1].

Customary law-based dispute settlement to minimize the high number of convicted persons is not an illogical alternative whose intensity of effectiveness certainty is somewhat doubtful. The hypothesis about the success of the strategy to resolve legal cases through customary law, in addition to its historical facts, has the inevitable potential of dealing that involves affirming the sense of kinship and social culture. Therefore, this idea is the last option that is able to silence anyone who commits a crime and makes them have an awareness of the nature of their life as a creation that has a high degree of position compared to other creatures. Furthermore, besides Indonesia has been doing since the days of empire in the past, 
mediation in customary law is a form of deliberation to reach consensus which is also mandated by Pancasila, the five basic principles of the Republic of Indonesia, as the basis and ideology of the Indonesian people [2].

The illustration above is a general description of the condition of prisons and prisoners in Indonesia. If it is examined more deeply, the condition can exceed what was informed in the previous section and thus it results in frequent riots which cause a large number of causalities and loss of property in the jail. Thus, efforts to resolve disputes between individuals or community groups with other individuals or other community groups are absolutely necessary in order to minimize the state losses in general and the losses of individuals in particular [3].

Specifically the study sought to offer an alternative strategy to reduce the number of prisoners who have to be dragged into prison through the application of traditional customary law. There are encouraging considerations to the offer of this alternative, one of which is that customary law carries the principle of resolving disputes or legal cases with a sense of family; mediation, an act that emphasizes neutrality in taking a decision on each case, is one of the elements of customary law; and the case settlement takes place quickly, transparently and and in a lowest cost. However, the first activities carried out are to identify the types of cases that can be resolved by customary law and to examine the procedures of customary justice so that decisions to be made fulfill the sense of justice for the community. On the other hand, this study highlights the level of community understanding of the existence of customary law and its essence, as well as the mechanism for applying customary law in solving certain cases effectively and without doubting [4].

This study was conducted using empirical legal research and socio legal research design. Investigation was conducted in four of the panitentiaries in Bali: The Kerobokan Badung panitentiary, the Gianyar panitentiary, the Negara panitentiary, and the Buleleng correctional institution. Data were collected through structured interviews containing a number of questions of prison and prisoners' conditions during 2017 and 2018. In addition, customary community heads in the region of each prison were interviewed to obtain information about the customary law rules commonly applied in resolving community cases. Furthermore that, information about the results was obtained from the settlement of disputes with customary law. Finally, the collected data were then analyzed with a qualitative approach, i.e., each result is explained descriptively [5].

\section{Results and Discussion}

\subsection{Outline of Panitentiary in Indonesia}

As mentioned in the previous section, most panitentiaries in Indonesia are filled with convicts whose number exceeds their actual capacity. Some of them are filled a number of convicts that is more than double of the actual capacity. Such a condition is really tramendeously as it has far exceeded what was predicted. Some prisons that are loaded with more than the actual capacity of prisoners' number are described below:

a. Pekan Baru panitetiary, Riau Province, has a maximum capacity of 330 people but is filled with 1050 prisoners.

b. Tanjung Gusta panitetiary, Medan City, has a maximum capacity of 1054 but people are filled with 2600 prisoners.

c. Class 2 panitetiary in Labuan Ruku, Batu Bara District of North Sumatra Province, has a maximum capacity of 251 people but filled with 867 prisoners. 
d. Class 2A panitetiary in Kerobokan, Bali province, has a maximum capacity of 360 people but is filled with 1100 prisoners.

e. Malabero Penitentiary, Bengkulu province, has a maximum capacity of 250 people but is filled with 758 prisoners.

f. Class 2A Penitentiary of Jambi has a maximum capacity of 380 people but is filled with 1700 inmates. (Source: Tempo.co, id May 8, 2017 edition accessed November 17, 2017).

The illustration above is a general description of prison conditions and convicts throughout Indonesia. However, if it is examined in more depth, these conditions can change with increasing number. As a result, riots that are vulnerable to causing causalities and property in vain, often occur. Thus, the idea of creating and discovering solutions to strive for the sttlement of every case that occurs between communities in order not to end in the jail absolutely must be raised. By this strategy, the high number of prisoners expectedly can be reduced, as well as causalities, riots, and the loss of property in the prison also decreases [6].

\subsection{Justice Existence in the Community}

In Indonesia the existence of customary justice is actually a necessity. It does have a vague form but the settlement of the vulnerable problems in the community is often executed by a customary law approach implementation, that is, in order to reach a consensus, a strategy of deliberation necessarily must be applied. In fact, the complexity of uniting and synthesizing the views, points of view, and ideas that are essentially never the same when discussing a dispute from various angles and aspects unavoidably stands, otherwise, ultimately the point is always obtained; it all ends in creating peace involving the principles of kinship. Notwithstanding, systematic and structured phases also should not be avoided, wherein; community dispute settlement activities through the customary law approach are realized in a series of consecutive stages. Dominant activities, which initiate every problem solving in a gathering is to convey or represent information about the poor condition of the prison and the prisoners who inhabit each panel. Delivery of this information must be done repeatedly, systematically, and in a structured way. [7] The second activity is to hold socialization to the policy makers about how much the cost to be borne by the state only to finance the lives of criminals in prison every year. This second activity must be done creatively and convincingly. For example, some logical reasons can be involved in expressions that convey the information, including explaining the functions and benefits of prisoners' living costs in other aspects, such as for infrastructure development that supports community activities: health institutions, educational institutions, and there are still many other aspects of human life that really need facilitation from the state [8].

Customary village leaders are introduced to the deliberation strategy. The public must be notified that deliberation aims to reach a consensus in the discussion of various cases involving the contradictory point of view of each participant. In addition, customary village leaders must be informed that the strategy was implemented long before the imprisonmentbased Dutch legal system was adopted and enforced in Indonesia. Prior to the first Indonesian colonization, the term prison had not been known in Indonesia because most legal and social cases and problems were settled jointly in accordance with the values of local wisdom. The main motivation of this study is the creation of efforts to develop the capacity and applicability of the local law or the customary law so that it is able to reach out and accommodate every social, legal, custom and religious problem that occurs among the community to be resolved through deliberation [4].

The results of the data analysis show that there are several legal cases that can be resolved customarily to avoid imprisonment, namely: 
a. Theft or embezzlement that causes a loss of not more than ten million rupiah.

b. Humiliation, defamation and adultery included in the classification of criminal types with pure complaints.

c. Corruption that causes a loss of not more than one hundred million rupiah.

d. A fight between two people and a mass fight.

e. Murder that is sincerely forgiven by the victim's family and the perpetrator admits his guilt and then apologizes and pays compensation.

f. Traffic accidents.

g. Sexual harassment.

h. Violence in the household.

i. Divorce cases.

j. The case in the division of inheritance which often leads to conflict and violence and even causes murder.

Unlike the ten criteria above, crimnal acts which are included as extraordinary crimes, such as drug abuse, terrorism, and corruption which cause losses of more than one hundred million rupiahs, must always be processed legally until the perpetrators of these types of crime are put in prison with maximum punishment.

\subsection{Procedures for Implementing Deliberation in Customary Law}

In general, the procedure for carrying out deliberation to reach consensus involves a series of coherent activities. The parties involved in the litigation: the victim represented by his family and the perpetrators are invited to the local village office escorted by the village security unit team. Notwithstanding, if security assistance from law enforcement officials is required, village officials can ask the Indonesian national police and army as a security team in the village court session. Regarding the costs needed for the activity, the first is obtained from the village cash. If the problem solving process has been completed and the party who has to bear the penalty has been determined, all costs have been paid by the the sentenced party [9].

Furthermore, there are several customary sanctions that can be imposed to the perpetrators of criminal acts. Average sanctions focus on compensating victims in the form of property and money. If a systematic procedure has been carried out during the dispute settlement process and various views, mandates, and good advice have been given, neverthless a good consensus could not be obtained, the next settlement is handed over to the police as an official authorized to conduct investigations and have high force in prosecuting the parties to the dispute. In other words, the legal process will take place in accordance with the provisions of the Criminal Procedure Code which lead to the imprisonment of perpetrators. As a consequence, efforts to reduce the number of prisoners in prison were unsuccessful [10].

However, whatever risks will raise the idea to settle matters in a customary manner should be given a good appreciation because of its proven efficacious potential in solving various kinds of disputes in a familial manner and that the awareness fostering in the perpetrators of crime and imprisonment is evaded. Behind all that, some difficulties in the application of customary law are often found, one of which is the quality of human resources that deal with these kinds of problems customarily in local villages. However, this difficulty can be overcome by providing coaching to village officials. Apart from that, with the quality of graduates that almost all families in every village have, positive, educative, and quality ideas can be raised in customarily settlement of each case instead of having the potential to be resolved in a national law that results in imprisonment. Therefore, with the large number of 
graduates in each village, every case and problem that occurs within the village environment can be ascertained that the settlement in a customary is effectively successful [6].

\subsection{Cases and Analysis}

Case:

In every community group, there are actually quite a number of criminal cases, the settlement of which is carried out customarily based on the spirit of deliberation to reach consensus. One of the cases that occurred in North Bali during mid-August 2018 was the destruction of a mini bus carried out by a group of people so that it had a criminal element. The settlement of the case tidak dilakukan di pengadilan. Indeed reports to the police have been made and with the discretionary authority held by the police, criminal cases of the bus destruction are settled at the police station with the mediation of the regional police chief. The consensus reached as a solution to the settlement of the problem was that prepetrators were required to pay reparation for the car as well as to pay compensation in the form of income earned from the bus in the amount of 200,000 (Two Hundred Thousand Rupiah) every day as long as the bus is still in the repair process at the garage. Overall, as the final settlement of this case the perpetrator pays Rp. 5,350,000,-; Rp. 3,350,000, - for repairing the bus damage; Rp. $1,000,000$,-for the bus compensation costs during repairs in the workshop; and Rp.1,000,000,for a driver who did not work for ten days [10].

\section{Analysis:}

From the above evidence, it is clear that settling disputes in deliberation under the implementation of customary law involving village officials which in Bali is referred to as Bendesa Adat, only requires a very lowest cost, performed in easy and quick way, and fulfills a sense of justice for the community and also the criminals not imprisoned. As a result, the number of prison inmates does not increase. It can be imagined that if the community and law enforcement agencies are able to wisely settle every legal problem whether it was criminal or civil, only efforts to minimize state enforcement could be effective [11].

In addition, the settlement of the mini bus destruction case above can be learned that all 7 perpetrators do not have to be dragged to prison. When compared with the settlement of disputes carried out in national law, it can be imagined how much money, energy and time must be spent in vain during the examination, the trial, until the process punishment process in prison. In addition, if the bus destruction is settled through national law, the damage would certainly not be repaired because the perpetrator had been dragged into prison, the imprisonment would also be a substitute for the penalty redemption by compensating the bus owner. Thus, the losses that must be borne by both parties involved in the case would be increasing [9].

\section{Conclusion}

Noting the problems that have been discussed based on the results of this study, there are two conclusions drawn, namely: Firstly, cases that deserve to be settled customarily in the form of deliberations to reach consensus are cases of crimes that do not include crimes that nationally threaten perpetrators for up to five years in prison. Examples of cases that can be settled by customary law are traffic accidents even though they cause casualties but on 
condition that the perpetrators want to provide compensation and the victims are willing to settle in a familial way. In addition, there are cases of fraud and embezzlement in a value of not more than one hundred million rupiah, cases of fights, destruction of objects, insults, defamation, sexual harassment, domestic violence, divorce, and so on. However, if a case is of huge potential and endanger the public in general, such as corruption, terrorism, narcotics, the settlement must be done through national law or criminal justice. Seconly, the procedures for resolving customary cases generally emphasize activities to create deliberations to reach consensus by being mediated by local adat elders and can be accompanied by law enforcement officers, especially the police.

Acknowledgements. The authors express the greatest gratitude to the organizing committee of the International Conference on Social Sciences (ICOSS) of Universitas Warmadewa for the great contribution that has been granted to the launching of this scientific script at EAI Publisher. Hopefully the ideas found in the paper can be additional to the theoretical and practical knowledge for many parties.

\section{References}

[1] A. \& Cahyadi, E, F, M.: Pengantar Filsafat Hukum. Jakarta, Kencana (2007)

[2] Pemerintah Republik Indonesia, Undang-Undang Dasar Negara Republik Indonesia Tahun 1945, p. 12 (2002)

[3] Dwi, I, Y.: Penerapan Hukum dalam Kasus Kekerasan Seksual terhadap Anak. Yogyakarta: Pustaka Yustisia (2015)

[4] Jamin.: Model Penguatan Peradilan Adat Dalam sistem Kekuasaan Kehakiman Sebagai Instrumen Desentrasilasi Keadilan Berdasarkan Konstitusi Yang Pluralis di Provinsi Bali. Solo, Universitas Sebelas Maret (2018)

[5] Moelong.: Metodologi Pengabdian Kualitatif. Bandung: Remaja Rosdakarya (2002)

[6] Astara, W.: Pertarungan Politik Hukum Negara dan Budaya Otonimi Desa Adat di Bali. Denpasar, Undayana Press (2015)

[7] Yantzi, M.: Kekerasan Seksual dan Pemulihan, Pemulihan Bagi Korban, Pelaku, dan Masyarakat, Judul asli, Sexual Offending and Restoration, Jakarta, PT. BPK. Gunung Mulia (2009)

[8] Prodjohamidjojo, M.: Penerapan Pembuktian Terbalik Dalam Delik Korupsi (UU no. 31 Tahun 1999). Bandung, Penerbit Mandar Maju (2001)

[9] Suena.: Tata Cara Penyelesaian Wicara Oleh Majelis Desa Pakraman Bali Denpasar. Denpasar: MUDP Bali (2012)

[10] Windia.: Tanya Jawab Hukum Adat, MUDP Bali, Denpasar. Denpasar, MUDP Bali (2010)

[11] Antara, I, W, K.: Pertarungan Politik Hukum dalam Kasus Kekerasan Otonomisasi Desa Adat. Denpasar: Udayana University Press (2010) 